\title{
Tata Kelola Konflik Dalam Pemilihan Kepala Desa di Kabupaten Bantaeng
}

\author{
Ahmad Taufik ${ }^{1}$, Hamrun ${ }^{1}$ \\ ${ }^{1}$ Program Studi Ilmu Pemerintahan \\ Fakultas Ilmu Sosial dan Ilmu Politik \\ Universitas Muhammadiyah Makassar \\ Jl Sultan Alauddin No 259 Makassar 90221 \\ Email: taufikunismuh@gmail.com
}

\begin{abstract}
This article would like to discuss about conflict management in village head election in Bantaeng District. The village as a community that has the boundaries of the region authorized to organize and manage the interests of local communities must not be separated from the main conflict in leadership succession. Especially after the village head elections are held openly and the process of sustainability is gaining control by the community. The type of research that is used is the type of qualitative research is the data expressed in the form of words, sentences, to provide a clear picture of the problems studied, interpret and explain the existing data systematically. This type of research is phenomenology and data analysis technique used is qualitative descriptive approach. In the results of research and discussion concluded that competing, collaborationing, compromising, avoiding, and accomonding become the steps of conflict resolution in village election in Bantaeng District.
\end{abstract}

Keywords: Conflict Governance, election of village head, Village Political Constellation

\begin{abstract}
ABSTRAK
Artikel ini ingin membahas tentang tata kelola konflik dalam pemilihan kepala desa di Kabupaten Bantaeng. Desa sebagai kesatuan masyarakat yang memiliki batas-batas wilayah yang berwenang untuk mengatur dan mengurus kepentingan masyarakat setempat tentunya tidak terlepas dari konflik utamanya dalam suksesi kepemimpinan. Utamanya setelah pemilihan kepala desa diadakan secara terbuka dan proses keberlangsungannya mendapatkan pengawasan oleh masyarakat. Jenis penelitian yang di gunakan adalah jenis penelitian kualitatif yaitu data dinyatakan dalm bentuk kata, kalimat, untuk memberikan gambaran secara jelas mengenai masalah-masalah yang diteliti, menginterprestasikan dan menjelaskan data yang ada secara sistematis. Tipe penelitian ini adalah fenomenologi dan teknik analisis data yang digunakan adalah pendekatan deskriptif kualitatif. Dalam hasil penelitian dan diskusi disimpulkan bahwa competing, collaborationing, compromising, avoiding, dan accomonding menjadi langkah-langkah penyelesaian konflik dalam pemelihan desa di Kabupaten Bantaeng.
\end{abstract}

Kata kunci: Tata Kelola Konflik, Pemilihan Kepala Desa, Konstalasi Politik Desa

\section{PENDAHULUAN}

Desa adalah kesatuan masyarakat yang memiliki batas-batas wilayah yang berwenang untuk mengatur dan mengurus kepentingan masyarakat setempat, berdasarkan asal usul dan adat istiadat setempat yang diakui dan dihormati dalam sistem Pemerintahan Negara Kesatuan Repulik Indonesia sebagai yang tersurat dalam pasal 1(5) PP No.72 Tahun 2005. Begitupula dalam UUD 1945 yang telah menegaskan bahwa Negara mengakui dan menghormati kesatuan masyarakat hukum adat beserta hak tradisionalnya sepanjang masih hidup dan sesuai dengan perkembangan masyarakat dan prinsip Negara RI.

Penyelenggaraan pemerintahan dan pembangunan Desa harus mampu mewujudkan partisipasi dan peran aktif masyarakat agar masyarakat senantiasa bertanggungjawab terhadap perkembangan kehidupan bersama sebagai warga desa. Pelaksanaan pembangunan desa ditujukan untuk 
meningkatkan taraf hidup dan kesejahteran masyarakat dengan kegiatan dan program sesuai dengan kebutuhan masyarakat.

Sistem pemerintahan yang ada tidak hanya diselenggarakan melalui struktur administrasi yang bersifat top down sebagaimana relasi kelembagaan antara pemerintahan kelurahan dengan pemerintahan kecamatan, melainkan juga dinamika politik antara elit desa yang dipilih secara langsung oleh warganya dengan perangkat desa yang juga merefleksikan warga desa. Artinya, kontestasi politik tidak saja berkutat pada konflik kepentingan antar lembaga pemerintahan desa, melainkan juga terjadi di antara aktor-aktor yang ada di tingkat desa itu sendiri, baik aktor-aktor formal maupun informal (Seftyono dkk, 2016).

Undang-Undang Tentang Pemerintahan Daerah mengakui adanya otonomi yang dimiliki oleh Desa dan kepada Desa dapat diberikan penugasan ataupun pendelegasian dari pemerintah ataupun pemerintah daerah untuk melaksanakan urusan pemerintah tertentu. Sedang terhadap desa diluar desa gineologis yaitu desa yang bersifat administratif seperti desa yang dibentuk karena pemekaran desa atau karena transmigrasi ataupun alasan lain yang warganya pluralistis, majemuk ataupun heterogen, maka otonomi Desa yang merupakan hak, wewenang, dan kewajiban untuk mengatur dan mengurus sendiri urusan pemerintahan dan kepentingan masyarakat berdasarkan hak asal usul dan nilai-nilai sosial budaya yang ada pada masyarakat setempat diberikan kesempatan untuk tumbuh dan berkembang mengikuti perkembangan desa itu sendiri.

Kepala Desa sebagai unsur penyelenggaraan pemerintahan di daerah kecil yaitu desa yang dipilih masyarakat secara langsung oleh penduduk desa yang memenuhi persyaratan yang berlaku dengan masa jabatan kepala Desa adalah 6 (enam) tahun dan ketentuan tentang Tata cara Pemilihan Kepala Desa Kepala Desa pada dasarnya bertanggungjawab pada rakyat desa dan prosedur pertanggung jawabannya disampaikan kepada Bupati/walikota melalui Camat.

Kepada Badan Permusyawaratan Desa (BPD) kepala Desa wajib memberikan keterangan laporan pertanggungjawaban dan menyampaikan informasi kepada rakyat tentang pokok-pokok pertanggungjawabannya. Masyarakat tetap diberi peluang untuk menanyakan lebih lanjut tentang pertanggungjawabannya. Lembaga Kemasyarakatan di Desa dibentuk untuk membantu pemerintah desa dan merupakan mitra dalam memberdayakan masyarakat. Lembaga ini berfungsi sebagai wadah partisipasi dalam pengelolaan pembangunan agar dapat terwujud demokratisasi dan transparansi pembangunan pada tingkat masyarakat dan untuk memotivasi masyarakat agar dapat berperan aktif dalam kegiatan pembangunan. Pemberdayaan masyarakat sangat diperlukan dalam pelaksanaan pembangunan yang ditujukan untuk meningkatkan taraf hidup dan kesejahteraan masyarakat melalui penetapan kebijakan program dan kegiatan sesuai dengan masalah dan prioritas kebutuhan masyarakat.

Demokrasi dalam konteks pemilihan Kepala Desa (Pilkades) dapat dipahami sebagai pengakuan keanekaragaman serta sikap politik partisipasif dari masyarakat dalam bingkai demokratisasi pada tingkat desa. Runtuhnya masa Orde Baru dan hadirnya liberalisasi politik membawa perubahan bagi kondisi sosial dan politik mulai dari tingkat lokal. Liberalisasi politik membuka ruang bagi setiap individu untuk turut serta berpartisipasi di panggung politik pemerintahan baik tingkal lokal hingga nasional. Hal ini memberikan angin segar bagi kalangan yang selama ini terpinggirkan karena status sosial (Razak \& Harakan, 2017).

Hal ini merujuk pada UU Nomor 8 Tahun 2005 tentang Perubahan atas UU No.32 Tahun 2004 tentang Pemerintahan Daerah yang mengakui penyelenggaraan pemerintahan desa sebagai subsistem dari sistem penyelenggaraan pemerintahan dimana desa berhak dan memiliki kewenangan untuk mengurus rumah tangga desa. Dengan diberinya kewenangan mengurus rumah tangga sendiri maka setiap stakeholder desa dituntut untuk mandiri dan bekerja keras dalam menentukan kepemimpinan di desa tersebut.

BPD memproses pemilihan kepala desa, paling lama 4 (empat) bulan sebelum berakhirnya masa jabatan kepala desa. Pada pasal 47 sampai 52 disebutkan bahwa untuk pencalonan dan 
pemilihan Kepala Desa, BPD membentuk Panitia Pemilihan yang terdiri dari unsur perangkat desa, pengurus lembaga kemasyarakatan, dan tokoh masyarakat. Panitia pemilihan melakukan pemeriksaan identitas bakal calon berdasarkan persyaratan yang ditentukan, melaksanakan pemungutan suara, dan melaporkan pelaksanaan pemilihan kepala Desa kepada BPD.

Panitia pemilihan melaksanakan penjaringan dan penyaringan bakal calon kepala Desa sesuai persyaratan. Calon kepala Desa yang telah memenuhi persyaratan ditetapkan sebagai Calon kepala Desa oleh Panitia Pemilihan. Calon kepala Desa yang berhak dipilih diumumkan kepada masyarakat ditempat-tempat yang terbuka dan calon kepala Desa dapat melakukan kampanye sesuai dengan kondisi sosial budaya masyarakat setempat.

Calon kepala Desa yang dinyatakan terpilih adalah calon yang mendapatkan dukungan suara terbanyak. Panitia pemilihan kepala Desa melaporkan hasil pemilihan Kepala Desa kepada BPD. Calon kepala Desa terpilih ditetapkan dengan Keputusan BPD berdasarkan laporan dan berita acara pemilihan dari panitia pemilihan. Calon kepala Desa terpilih disampaikan oleh BPD kepada Bupati/Walikota melalui Camat untuk disahkan menjadi kepala Desa terpilih. Bupati/Walikota menerbitkan keputusan tentang pengesahan pengangkatan kepala Desa terpilih paling lama 15 (lima belas) hari terhitung tanggal diterimanya penyampaian hasil pemilihan dari BPD.

Pelaksanaan pilkades tidak jarang menuai kericuhan dan konflik, Timbulnya konflik pemilihan kepala Desa yang berkepanjangan akibat fanatisme, redahnya kesadaran masyrakat terhadap hukum dan kerasnya konfrontasi pendukung calon kepala desa yang secara tatap muka saling memperjuangkan kemenangan calon masing-masing. Bahkan kadang telah melupakan nilai dari demokrasi dan melunturkan nilai etika yang selama ini tertanam dalam masyarakat desa. Konflik diawali dengan ketidak puasan, berbagai rasa curiga atas kemenangan calon terpilih.

Kampanye-kampanye yang dilakukan oleh masing-masing kandidat melalui tim suksesnya masing-masing ada yagn bersifat mengajak dan ada juga yang bersifat memaksa serta mengancam warga yang seandainya tidak memilih mereka nantinya, tidak akan dibantu maksimal seandainya kandidat tersebut menang dalam pemilihan kepala desa. Tentunya hal ini memicup prahara di masyarakat yang mersa tidak nyaman oleh tingkah laku para kandidat kepala desa. Pasca namanama kandidat telah diumumkan sebagai calon oleh tim pemilihan kepala desa kampanye yang dilancarkan oleh lima kandidat tersebut semakin memanas, padahal masing-masing kandidat notabenenya masih merupakan kerabat.

Kampanye-kampaye hitam menjelek-jelekkan masing-masing calon yang dilakukan oleh masing-masing tim sukses memicu keributan antar tim sukses yang mana nyaris berdampak pada bentrokan fisik. Hal ini diakui oleh ketua BPD Sulaiman yang pada waktu itu menjabat sebagai ketua BPD Desa Batukaraeng. Akibat ulah para tim sukses masing-masing calon membuat masyarakat Batukaraeng yang terdiri dari tiga dusun terkotak- kotak tentunya hal ini telah mengarah kepada perang dingin yang ketika pecahakan berujung pada konflik fisik.

Tidak sehatnya pola kampanye yang dilakukan oleh masing-masing calon dan timnya mengajarkan politik yang tidak baik kepada masyarakat yang tida sesuai dengan jiwa bangsa yaitu musyawarah mufakat dalam pemilihan kepala desa yang mana masing-masing calon seharusnya berkampanye dengan santun. Namun karena pemilihannya adalah satu orang satu suara mengakibatkan pola politik yang dibangun tidak sehat. Disatu sisi dalam pemilihan kepala desa ini money politik juga menjadi tren yang mengakibatkan rusaknya pola pemikiran masyarakat, akibatnya tidak lagi memilih calon yang memiliki kemampuan dan integritas dalam memimpin desa Batukaraeng.

Situasi yang memprihatinkan seperti ini sering terjadi di berbagai daerah Desa yang terdapat ditanah air Indonesia, seperti misalnya yang terjadi di Desa Batukaraeng Kecamatan Pa'jukukang Kabupaten Bantaeng. Proses pelaksanaan pilkades diwarnai dengan persaingan tidak sehat mulai dari penutupan saluran irigasi oleh pendukung salah satu calon, pemutusan aliran listrik antara pendukumg calon, sampai pada penghinaan dan pengancaman yang akhirnya menuai konflik. 
Masyarakat Desa Batukaraeng Kecamatan Pa'jukukang Kabupaten Bantaeng pada umumnya masih menjujung tinggi nilai-nilai persatuan dan kekeluargaan, akan tetapi kuatnya nilai-nilai tersebut melemah ketika bersinggungan dengan pemilihan kepala Desa (pilkades), masyarakat justru mementingkan kepentingan politiknya yaitu berusaha semaksimal mungkin untuk memenangkan calon yang diusung dan mengalahkan calon lain sebagai lawan politiknya.

Penyelenggraan pesta demokrasi ini terdapat banyak masalah dan persoalan sebagai gejala awal konflik pilkades yang diwarnai dengan ancaman, pencemaran nama baik dan kekerasan yang memungkinkan masyarakat untuk berhadapan dengan pihak yang berwajib dalam hal ini kepolisian. Konflik pemilihan kepala di Desa Batukaraeng Kecamatan Pa'jukukang Kabupaten Bantaeng, semakin menarik untuk dibahas mengingat pentingnya keberlangsungan kehidupan masyarakat Desa yang tertib, aman, dan damai. Diperlukan langkah-langkah bijak para pihak yang bertikai, melepaskan ego kekuasaan untuk memikirkan jalan terbaik sebagai tanggungjawab moral demi kepentingan rakyat, agar tidak berdampak pada penyelenggaraan pemerintaha Desa dalam meninggakatan pelayanan publik serta kesejahteraan masyarakat.

\section{TINJAUAN PUSTAKA}

\section{Teori Konflik}

Teori-teori utama mengenai sebab-sebab konflik adalah:

Teori hubungan masyarakat

Menganggap bahwa konflik disebabkan oleh polarisasi yang terus terjadi, ketidak percayaan dan permusuhan di antara kelompok yang berbeda dalam suatu masyarakat. Sasaran: meningkatkan komunikasi dan saling pengertian antara kelompok yang mengalami konflik, serta mengusahakan toleransi agar masyarakat lebih bisa saling menerima keragaman yang ada didalamnya.

\section{a. Teori kebutuhan manusia}

Menganggap bahwa konflik yang berakar disebabkan oleh kebutuhan dasar manusia (fisik, mental dan sosial) yang tidak terpenuhi atau dihalangi. Hal yang sering menjadi inti pembicaraan adalah keamanan, identitas, pengakuan, partisipasi, dan otonomi.

Sasaran: mengidentifikasi dan mengupayakan bersama kebutuhan mereka yang tidak terpenuhi, serta menghasilkan pilihan-pilihan untuk memenuhi kebutuhan itu.

\section{b. Teori negosiasi prinsip}

Menganggap bahwa konflik disebabkan oleh posisi-posisi yang tidak selaras dan perbedaan pandangan tentang konflik oleh pihak-pihak yang mengalami konflik.

Sasaran: membantu pihak yang berkonflik untuk memisahkan perasaan pribadi dengan berbagai masalah dan isu dan memampukan mereka untuk melakukan negosiasi berdasarkan kepentingan mereka daripada posisi tertentu yang sudah tetap. Kemudian melancarkan proses kesepakatan yang menguntungkan kedua belah pihak atau semua pihak.

\section{c. Teori identitas}

Berasumsi bahwa konflik disebabkan oleh identitas yang terancam, yang sering berakar pada hilangnya sesuatu atau penderitaan di masa lalu yang tidak diselesaikan. 
Sasaran: melalui fasilitas lokakarya dan dialog antara pihak-pihak yang mengalami konflik, sehingga dapat mengidentifikasi ancaman dan ketakutan di antara pihak tersebut dan membangun empati dan rekonsiliasi di antara mereka.

d. Teori kesalah pahaman antar budaya

Berasumsi bahwa konflik disebabkan oleh ketidakcocokan dalam cara-cara komunikasi di antara berbagai budaya yang berbeda. Sasaran: menambah pengetahuan kepada pihak yang berkonflik mengenai budaya pihak lain, mengurangi streotip negatif yang mereka miliki tentang pihak lain, meningkatkan keefektifan komunikasi antarbudaya.

e. Teori transformasi konflik

Berasumsi bahwa konflik disebabkan oleh masalah-masalah ketidaksetaraan dan ketidakadilan yang muncul sebagai masalah sosial, budaya dan ekonomi.

Sasaran: mengubah struktur dan kerangka kerja yang menyebabkan ketidaksetaraan dan ketidakadilan termasuk kesenjangan ekonomi, meningkatkan jalinan hubungan dan sikap jangka panjang di antar pihak yang berkonflik, mengembangkan proses dan sistem untuk mempromosikan Pemberdayaan, Keadilan, Perdamaian, Pengampunan, Rekonsiliasi, Pengakuan. (Fisher, dkkk. 2002.)

\section{Pengelolaan Konflik}

Menurut Hardjana, A. M. (1994), mengemukakan teknik-teknik pengelolaan konflik yaitu: a. Bersaing (compotiting)

Bersain merupakan pendekatan terhadap konflik yang berciri menang-kalah (win-lose approach). Salah satu pihak memperjuangkan kepentingannya dengan mengerbankan kepentingan pihak lain. Sedangkan tujuannya mendapatkan yang diperjuangkan dan mengalahkan pihak lain.

b. Kerjasam (collaboratioing)

Kerjasam (collaboratioing) kedua pihak yang terlibat konflik bekerja sama dan mencari pemecahan konflik yang dapat memuaskan kepentingan kedua belah pihak. Penegelolaan konflik menggunakan teknik kerjasama merupakan pendekatan menang-menang (win-win approach). Tujuan pendekatan ini masing-masing mendapatkan yang di inginkan.

c. Kompromi (compromising)

Kompromi sebgai salah satu teknik penyelesaian konflik mengharuskan kedua pihak yang terlibat konflik saling memberi kelonggaran atau konsesi. Keduanya saling bekerjasama untuk menyelesaikan konflik tanpa mengorbankan kepentinagan oragnisasi. Pendekatan kompromi dapat memuaskan kedua pihak yang terlibat konflik karena tidak ada yang menang atau kalah.

d. Menyusuaikan (acomonding)

Pendekatan menyusuaikan (acomonding) dilakukan oleh pihak-pihak yang terlibat konflik dengan cara salah satu pihak melepas atau mengesampingkan keinginan kelompoknya dan memenuhi keinginan pihak lain. Melalui pendekatan ini, pihak yang satu merelakan kebutuhannya sehingga pihak lain mendapatkan sepenuhnya hal yang diinginkan. Teknik penyesuaiaan merupakan pendekatan kalah-menang (lose-win approach).

Asumsi setiap orang memiliki kecenderungan tertentu dalam menangani konflik.Terdapat 5 kecenderungan: 

a. Penolakan: konflik menyebabkan tidakn yaman.
b. Kompetisi: konflik memunculkan pemenang
c. Kompromi: ada kompromi dan negosiasi dalam konflik untuk meminimalisasi kerugian
d. Akomodasi: ada pengorbanan tujuan pribadi untuk mempertahankan hubungan.
e. Kolaborasi: mementingkan dukungan dan kesadaran pihak lain untuk bekerja bersama-sama

\section{METODE PENELITIAN}

Jenis penelitian yang di gunakan adalah jenis penelitian kualitatif yaitu data dinyatakan dalm bentuk kata, kalimat, untuk memberikan gambaran secara jelas mengenai masalah-masalah yang diteliti, menginterprestasikan dan menjelaskan data yang ada secara sistematis.

Tipe penelitian ini adalah fenomenologi yaitu peneliti akan mendeskripsikan pengalaman yang dilakukan dan dialami oleh informan berkaitan dengan konflik pemilihan Desa di Batukaraeng Kec. Pa'jukukan Kab. Bantaeng . Sumber data di peroleh dari Data primer yaitu data yang diperoleh melalui hasil observasi dan wawancara, dan data sekunder yaitu data yang dikumpulkan peneliti yang sumbernya dari data-data sebelumnya menjadi seperangkat informasi dalam bentuk dokumen, laporan-laporan, dan informasi tertulis lainnya yang berkaitan dengan objek penelitian.Teknik pengumpulan data yang digunakan adalah observasi, wawancara dan dokumentasi. Teknik analisis data yang digunakan adalah pendekatan deskriptif kualitatif.

\section{HASIL DAN PEMBAHASAN}

\section{Penyelesaian Konflik Pemilihan Kepala Desa di Desa Batukaraeng Kecamatan Pa'jukukang Kabupaten Bantaeng.}

Langkah-langkah dalam menyelesaikan konflik pemilihan Desa Batukaraeng Kecamatan Pa'jukukang Kabupaten Bantaeng namun pada bagian ini peneliti kembali mempertegas bahwa yang menjadi langkah dalam penyelesaian konflik adalah melalui pendekatan Menurut Hardjana, A. M. (1994), mengemukakan teknik-teknik pengelolaan konflik yaitu: (1) Bersaing (compotiting) (2) Kerjasama (collaboratioing) (3) Kompromi (compromising) (4), Menghindari (avoiding), dan (5) Menyusuaikan (acomonding), sebagaimana penjelasan berikut:

\section{Bersaing (competing)}

Banyaknya rentetan konflik yang terjadi pasca pemilihan Kepala Desa tentunya promatur yang terpilih maupun yang tidak terpilih bersaing dalam melakukan pendekatan baik pendekatan kepada masyarakat maupun pendekatan terhadap pemerintah dalam hal ini Pemerintah Daerah Kabupaten Bantaeng, dan terbukti bahwa promatur yang terpilih berhasil melakukan komunikasi kepada Pemerintah Daerah sehingga pelantikan Kepala Desa dapat di lakukan meskipun meninggalkan kesan serta ketimpangan-ketimpangan yang ada. Menurut informan AB selaku warga masyarakat setempat mengatakan bahwa:

"...Menurut saya pak Desa yang terpilih saat itu dia melakukan pendekatan dengan Pak Bupati dan jajaran Pemerintah daerah lainnya sehingga pelantikan bisa di lakukan,meskipun masih 
banyak gesekan-gesekan masyarakat di antara pendukung serta konflik masih ada di Desa Batukareng bupati tetap bersikeras melakukan pelantikan dan pelantikan itu tidak di lakukan di kantor desa tapi pelantikan itu dilakukan pada gedung pertiwi Kabupaten Bantaeng" (Hasil wawancara AB , 2 Februari 2016)

Berdasarkan pernyataan di atas tentunya dalam hal manajemen konflik pemilihan Kepala Desa yang di laksanakan dapat kita melihat bahwa pendekatan yang di lakukan oleh Formatur yang terpilih lebih cendrung kepada persaingan untuk merebut perhatian Pemerintah Daerah dalam bekerjasama untuk mewujudkan pelaksanaan pelantikan agar promatur yang terpilih dianggap sah menjadi Pemerintah Desa Batukaraeng. Sebagaimana yang di kemukakan oleh informan RP selaku tokoh masyarakat.

“...Memang sebelum adanya pemilihan kepala Desa yang di lakukan, Menurut saya sudah ada pendekatan yang di lakukan oleh calon terpilih terhadap pak Bupati sebelumnya, karena sepertinya Bupati merestui pak Desa yang terpilih untuk menjabat sebagai Kepalaa Desa Batukaraeng" (Hasil wawancara RP, 10 Februari 2016).

Persaingan-persaingan yang terlahir bukan hanya berbentuk pendekatan yang di lakukan kepada pihak pemerintah namun ketika kembali menyimak sedikit prosesi tentang masa kampanye sebelum berlangsungnya pemilihan Kepala Desa, para calon kepala Desa aktif dalam melakukan berbagai hal untuk merebut simpati masyrakat mulai dari persaingan yang bentuk fisik maupun persaingan-persaingan berbentuk nonfisik. Kemudian persaingan yang di lakukan pasca pemilihan adalah persaingan dalam hal melakukan pendekatan terhadap masyarakat agar bisa mempengaruhi dan merubah haluan masyarakat dari yang sepakat menjadi tidak sepakat maupun dari yang tidak sepakat menjadi sepakat.

\section{Kerjasama (collaborating)}

Kondisi tidak aman dalam wilayah Desa Batukaraeng pasca pemilihan sangat menekan fisikologi masyarakat karena pada saat itu banyak kelompok-kelompok yang saling mengancam dan saling mengganggu antara satu dengan yang lainnya terutama anata pihak yang kalah dengan pihak yang menang dalam pertarungan pemilihan kepala Desa tersebut. Di tengah maraknya konflik para pendukung berat ketiga calon yang kalah mengambil kesempatan untuk melakukan konsolidasi dalam upaya bekerja sama untuk menumbangkan promatur yang terpilih.

Dalam konsolidasi yang dilakukan di antara ketiga calon yang kalah menghasilkan kesepakatan untuk bekerjasama mengarahkan massa dalam melakukan aksi unjuk rasa yang berlokasi pada kantor Dewan Perwakilan Rakyat Daerah Kabupaten Bantaeng (DPRD), dan kantor Bupati Bantaeng dengan menyatakan sikap bahwa menolak keras ketika Pemerintah Kabupaten Bantaeng melakukan pelantikan atas promatur yang terpilih dengan alasan banyaknya kecurangn-kecurangan yang dapat masyarakat rasakan pada pemilihan kepala desa Batukaraeng. Pada saat aksi unjukrasa di lakukan tepatnya pada tanggal 26 Agustus 2015 dengan massa sekitar kurang lebih 100 orang di mobilisasi oleh ketiga calon kepala Desa yang di kalah. Berdasarkan hasil wawancawa dengan bapah $\mathrm{AB}$ dikatahkan sebagai berikut :

"Kami melakukan demo di kantor pemerintah kabupaten bantaeng karena tidak sepakat dengan keputusan semua aparatur yang terkait dalam petugas pelaksana pemilihan kepala desa lonrong karena kami melihat banyak masalah-masalah yang ada dalam proses pemilihan meskipun kami tidak punya bukti nyata dan bukti pisik yang bias menguatkan tuntutan kami" (Hasil wawancara AB, 10 Februari 2016) 
Dari pernyataan tersebut di atas memberikan bukti bahwa di dalam proses pemilihan Kepala Desa memang terdapat ketimpangan yang sempat masyarakat saksikan, namun berbeda dengan pendapat informan A A selaku panitia pelaksana pemilihan Kepala Desa yang menururkan sebagai berikut :

"Dari beberapa kegiatan-kegiatan yang di lakukan dengan bentuk penolakan atau ketidak sepakatan akan terpilihnya calon kepala desa yang terpilih adalah hal yang biasa terjadi dalam prosesi pemilihan atau pesta demokrasi,karena memang ada pihak yang berupaya propokasi dan memobilisasi masyarakat agar tidak sepakat dengan calon yang terpilih. Proses pemilihan berlangsung dengan jujur dan adil, mereka melakukan aksi-aksi penrusakan mungkin karena tidak siap menerima kekalahan" (Hasil wawancara A A, 24 Februari 2015).

Melihat pandangan dari kedua informan di atas tentunya mengandung penertian bahwa dalam pemilihan Kepala Desa hingga proses pelantikan banyak terjadi pertentangan dan perbedaan presepsi dalam menilai beberapa kejadian contohnya saja aksi unjuk rasa yang di lakukan dalam hal menolak di laksanakannya pelantikan menuai kontropersi masyarakat dalam menilai, ada yang menanggapi kejadian itu merupakan hal yang positif karena bnyaknya ketimpangan dan penyimpangan yang ada daalam proses pemilihan. Adapula yang menanggapi penomena itu merupakan sebuah hal yang negetif dan tidak berguna yang hanya menimbulkan keresahan dalam lingkungan masyarakat terutama masyarakat desa lonrong.

\section{Kompromi (compromising),}

Konflik-konflik yang terjadi tentunya memiliki sebab akibat yang timbul dikarenakan oleh gesekan antara beberapa pihak yang ada. Oleh karena itu pemerintah dengan pihak yang menang dalam pemilihan Kepala Desa bekerja sama untuk mengakomodasi masyarakat dalam bentuk mengharuskan pihak-pihak yang terlibat saling memberikan kebebasan dalam berpendapat demi terwujudnya sikap saling menghargai untuk penyelesaian konflik. Pendekatan yang di lakukan oleh pemerintah daerah dengan pemerintah tingkat Desa adalah berupaya melakukan sosialisasi kepada tokoh-tokoh masyarakat yang berpengaruh kepada masyarakat Desa Batukaraeng pada umumnya dan menyarankan kepada tokoh masyarakat agar meyakinkan bahwa tidak ada penyimpangan yang terjadi pada pihak-pihak yang kontra dengan keputusan hasil pemilihan Kepala Desa.

Pendekatan dengan cara kompromi di lakukan oleh beberapa pihak yang tentunya termasuk aparatur Desa, Pemerintah Daerah, Serta tokoh-tokoh masyarakat yang punya pengaruh besar terhadap masyarakat Desa Batukaraeng Kecamatan Pa'jukukang Kabupaten Bantaeng. Kompromi yang di lakukan pihak-pihak tersebut di antaranya adalah melakukan sosialisasi kepada calon kepala Desa serta tim-tim yang memperkuat kelompok calon tersebut meyakinkan bahwa tidak ada kecurangan dalam pemilihan tersebut hanya terdapat kesalah pahaman sehingga timbul pertentangan yang menghadirkan konflik antara golongan-golongan masyarakat, sebagama yang di tuturkan informan AJ selaku Toko Agama Desa Batukaraeng.

"saya pribadi memang melihat beberapa kekacauan yang timbul akibat dari pemilihan Kepala Desa tersebut, oleh karenanya saya terdorong untuk melakukan pendekatan pada tokohtokoh pengusung calon kepala desa yang sengajah melakukan propokasi agar menghentikan aksinya tentunya demi melihat kembali kedamaian desa ini yang memang pelaku konflik adalah kami para warga masyarakat desa setempat"(wawancara bapak AJ di lakukan pada tanggal 26 Februari 2016) 
Dari pernyataan di atas menggambarkan bentuk kepedulian tokoh-tokoh setempat dalam hal mewujudkan perdamaian sama halnya dengan pembicaraan yang dituturkan oleh informan $\mathrm{MH}$ selaku tokoh Pemuda Desa Batukaraeng menyatakan bahwa:

"dalam upaya mewujudkan perdamaian dari konflik-konflik yang ada maka kami dari beberapa tokoh masyarakat melakukan semacam musyawarah untuk pendekatan terhadap beberapa pihak dalam hal meluruskan kesalah pahaman serta menawarkan perdamaian karena memang saya menganggap bahwa konflik yang menimpa masyarakat itu adalah akibat dari kerjakerja beberapa orang yang melakukan propokasi terutama pihak-pihak yang kecewa karena kekalahan dalam pertarungan pemilihan kepala desa"(wawancara bapak MH di lakukan pada tanggal 26 Februari 2016).

Pernyataan yang di tuturkan oleh informan AJ dan MH juga sama dengan pernyataan yang di berikan oleh GFW selaku Kepala Desa yang terpilih yang mengatakan bahwa :

"saya sebagai kepala desa yang terpilih tentunya juga tidak tinggal diam dalam melihat pertentangan antara masyarakat saya sendiri,secara pribadi saya juga menyadari bahwa ini adalah bagian dari tanggung jawab saya sebagai pemerintah yang terpilih,makanya saat itu saya juga turut membantu tokoh-tokoh masyarakat dalam upaya melakukan pendekatan terutama pendekatan kepada keluarga sendiri karena di dalam pemilihan ini banyak juga keluarga saya yang menjadi lawan politik, maka dari itu saya mengawali pendekatan pada saat itu dengan mendatangi keluarga-keluarga lawan politik yang saya maksud"'(wawancara bpk GFW di lakukan pada tanggal 29 Februari 2016)

Partisipasi tokoh masyarakat dalam upaya mewujudkan perdamaian dengan cara melakukan kompromi kepada pihak pihak yang berpengaru dalam konflik yang ada merupakan partisipasi yang luar biasa karena cara ini menjadi salah satu penyebab hadirnya perdamaian dari konflik-konflik yang terjadi sehingga seluruh masyarakat Desa Batukaraeng Kecamatan Pa'jukukang Kabupaten Bantaeng merasakan perdamaian dan kesejahtraan sampai sekarang.

\section{Menghindari (avoiding)}

Menghindar atau menarik diri adalah salah satu manajemen konflik yang juga di lakukan untuk menanagni konflik-konflik yang timbul pasca pemilihan kepala Desa Batukaraeng. Seiring banyaknya konflik yang terjadi tentunya pemerintah juga tidak tinggal diam akan tetapi juga berperan aktif dalam berupaya untuk menciptakan perdamaian, Hasilnya adalah berkat dorongan dan masukan pihak Pemerintah Daerah para kandidat yang tidak terpilih maupun yang terpilih melakukan upaya-upaya untuk menghindari segala hal yang bisa menimbulkan konflik dalam bentuk apapun.

Dalam upaya menghindari pemicu konflik yang terjadi, pihak-pihak yang terkait penting dengan pemilihan memang jarang terlihat karena mereka bersama-sama menghindar dan menarik diri dari segala potensi konflik yang mungkin terjadi sehingga pada saat itu yang lebih dominan dalam penanganan dan upaya menyelesaikan konflik adalah tokoh-tokoh masyarakat yang ada di Desa Batukaraeng. Sebagaimana pernyataan yang di paparkan oleh informan MS selaku anggota BPD Desa Batukaraeng :

“...di sini saya memang melihat di antara semua calon jarang terlihat apalagi calon yang menang di pemilihan Desa, katanya itu adalah sala satu cara yang di lakukan untuk menghindari 
adanya konflik. Pas setelah pemilihan di lakukan Pak desa hampir tidak pernah saya lihat, nah yang juga punya peran dalam mendamaikan masyarakat yang berkonflik adalah bapak Sahabuddin berhubung karena beliau adalah mantan kepala desa pastinya masih punya pengaruh besar terhadap masyarakat"(wawancara bapak MS di lakukan pada tanggal 29 Februari 2016)

Dari pernyataan tersebut di atas dapat menggambarkan peranan dari beberapa calon yang berupaya unyuk mewujudkan sebuah perdamaian sebagaimana di perkuat okeh pernyataan informan DMW selaku Sekretariat Desa Batukaraeng mengatakan bahwa :

“...setelah melihat konflik-konflik yang ada pemerintah daerah bekerjasama dengan jajarannnya memang sudah memberikan arahan kepada para calon kepala desa baik yang terpilih maupun yang tidak terpilih agar menjaga sikap untuk sementara demi menghindari konflik susulan" (wawancara ibu DMW di lakukan pada tanggal 29 Februari 2016)

Sesuai pernyataan informan MS, dan informan DMW memiliki persepsi yang sama dengan pernyataan yang dituturkan oleh informan J R selaku Ketua panitia pelaksana pemilihan Kepala Desa yang mengatakan:

“,..ya memang pada saat itu pemerintah punya peran penting terhadap pengololaan konflik, pak camat beserta orang-orangnya juga melakukan pendekatan dan sosialisasi terhadap masyarakat-masyarakat yang bisa di jangkau berhubung karena aparatur-aparatur serta kepala desa yang terpilih di arahkan untuktidak punya aktipitas dulu untuk sementara waktu"(wawancara bapak J R di lakukan pada tanggal 29 Februari 2016)

Berdasarkan beberapa pernyataan informan peneliti dapat menganalisa dan memahami bahwa dalam pengelolaan konflik pasca pemilihan Kepala Desa Batukaraeng pemerintah memiliki peran aktif bekerja sama dengan tokoh-tokoh masyarakat setempat sehingga dalam mengarahkan calon-calon untuk tidak beraktifitas, Pemerintah tidak hanya sekedar mengarahkan akan tetapi memiliki strategi tersendiri untuk meredam perilaku propokasi serta menyadarkan masyarakat akan tidak adanya kecurangan yang di lakukan oleh pemerintah serta aparat-aparat yang terkait dalam proses pemilihan Kepala Desa Batukaraeng Kecamatan Pa’jukukang Kabupaten Bantaeng.

\section{Menyesuaikan (accomoding)}

Pendekatan menyesuaikan di lakukan oleh pihak-pihak yang terlibat konflik dalam artian calon Kepala Desa yang dengan cara salah satu pihak melepaskan atau mengesampingkan keinginan kelompoknya dan memenuhi keinginan pihak lain. Melalui pendekatan ini pihak yang satu merelakan kebutuhannya, sehingga pihak lain mendapatkan sepenuhnya yang diinginkan.

Seiring berjalannya waktu pasca pemilihan Kepala Desa terlihat bahwa di antara beberapa calon atau kandidat yang kalah di pertarungan secara perlahan telah menerima kekalahan dan tentunya itu semua tidak lepas dari kerjasama antara pemerintah setempat, Tokoh-tokoh masyarakat serta jajaran Pemerintah Kecamatan dan Pemerintah Daerah yang selalu beruaha untuk melakukan pendekatan kepada pihak-pihak yang kontra atas keputusan yang di keluarkan oleh lembaga pemungutan suara pemilihan Kepala Desa. Dari pendekatan manajemen konflik dengan cara menyesuaikan informan S HT selaku kepala dusun Bonto te'ne menuturkan :

“...dari ketegasan bapak bupati bantaeng untuk melakukan pelantikan masyarakat menganggap tidak ada lagi harapan biarpun selalu menuntut keputusan hasil pemilihan karena memang tuntutan yang di buat sebelum pelantikan saja sepertinya tidak terlalu menarik perhatian 
pak bupati, malahan dari banyaknya protes yang di lakukan membuat pemerintah daerah buruburu melakukan pelantikan"'(wawancara bapak S HT di lakukan pada tanggal 29 Februari 2016)

Berdasarkan uraian serta informasi dari masyarakat bahwa proses pelantikan dilakukan meskipun masih banyak terjadi konflik dan tuntutan-tuntutan dari masyarakat merupakan strategi pemerintah dalam upaya meredam konflik-konflik yang ada, Pemerintah meyakini bahwa terjadinya konflik hanya di sebabkan oleh kesalah pahaman dan di perparah oleh aksi propokasi yang di lakukan oleh beberapa pihak. Mengenai proseses pelantikan informan HS selaku Kepala Dusun Ma'le'ro menuturkan :

“...kenapa proses pelantikan tidak di laksanakan pada kantor desa lonrong? Itu membuktikan bahwa pada saat di laksanakannya pelantikan itu masih banyak masalah yang terjadi di desa ini, Makanya pak Bupati melakukan pelantikannya di gedung pertiwi yang ada di kota bantaeng demi menghindari adanya pertentangan lagi"(wawancara bapak HS di lakukan pada tanggal 29 Februari 2016)

Dari pernyataan informan S HT, dn informan HS diatas. hasil wawancara dengan informan SM selaku Kepala Dusun Batukaraeng menuturhan hal yang sama, bahwa:

“...pelantikan yang bisa di katakan pak bupati mempercapat sedikit pelantikannya mungkin adalah taktik juga untuk menyelesaikan konflik beberapa pertentangan yang ada, tetapi yang saya pahami kepala desa yang terpilih itu memang mendapat restu dari pak Bupati berhubung karena orang tua (Bapak) dari Kepala Desa yang terpilih sekarang itukan pernah menjadi Kepala Desa disini"(wawancara bapak SM di lakukan pada tanggal 29 Februari 2016)

Dalam pemilihan Kepala Desa hampir selalu di sertai dengan konflik karena menjadi esensi kehidupan manusia, konflik yang muncul dipermukaan dalam kompetisi politik tentunya di akibatkan oleh berbagai alasan baik yang di timbulkan karena adanya ketimpangan dalam proses pemilihan hingga alasan adanya propokasi yang di lakukan baik pihak-pihak yang terkait

\section{KESIMPULAN}

Faktor penyebab terjadinya konflik pemilihan Kepala Desa di Batukaraeng Kecamatan Pa'jukukang Kabupaten Bantaeng yaitu : (1) Kurangnya Kesadaran Masyarakat Terhadap Hukum, Peraturan Bupati Bantaeng No 5 Tahun 2015 Tentang Pedoman Pelaksanaan Pemilihan Kepala Desa peniadaan pemilihan ulang, tetapi masyarakat mengharapkan pemilihan ulang karena dianggap banyak kecurangan dan suara calon ada yang sama. (2) Fanatisme Berlebihan, Ada tim pendukung terlalu mengidolakan dan melebih-lebihkan keluarganya yang lebih pantas jadi kepala desa. Namun ada informan mengatakan bukan fanatik karena jauh sebelumnya ada pembentukan tim sukses dan bekerja sesuai intruksi. (3) Adanya Dugaan Surat Panggilan Siluman, Adanya anggapan salah satu calon bekerja sama dengan panitia mendatangkan massa atau panggilan hak suara dari derah lain, sementara orang luar yang dimaksud punya dua rumah, di Desa Batukareng dan di kelurahan Bonto Rita. (4) Adanya Pemaksaaan, Masyarakat menganggap terjadi paksaan untuk memilih salah satu calon dengan melakukan tekanan dan ancaman. dan (5) Maraknya Money. Adanya politik uang dilakukan salah satu calon juga diakui pemerintah setempat dan masyarakat, dan ada calon minta dikembalikan uangnya karena kalah.

Langkah-langkah penyelesaian konflik pemilihan Kepala Desa di Desa Batukaraeng Kecamatan Pa'jukukang Kabupaten Bantaeng yaitu: (1) Bersaing (competing), Persaingan lebih 
pada kedekatan dan meraih simpati Pemerintah Daerah dalam hal ini Bupati Bantaeng yang sudah menjadi idola bagi masyarakat, dilakukan oleh salah satu calon Desa. (2) Kerjasama (collaborationing), Untuk meredam konflik 3 calon bekerja sama melakukan aksi protes atas hasil pemilihan, aksi ini ditanggapi positif dan negative oleh masyarakat. (3) Kompromi (compromising), Pemerintah Daerah, kepala Desa terpilih dan tokoh masyarakat mengakomodasi masyarakat dalam kebebasan berpendapat demi terwujudnya sikap saling menghargai satu sama lain adalah cara terbaik menyelasaikan konflik (4), Menghindari (avoiding), Pemerintah berperan aktif dalam menyelesaikan konflik, sehingga masyarakat kedua belah pihak sama-sama tarik diri dan menghindari konflik, dan (5) Menyusuaikan (accomonding), Tidak adanya tekanan yang berlebihan dilakukan pak Desa terpilih terhadap lawan konflik, sehingga secara perlahan lawan menerimah dan menyusuaikan keadaan hasil keputusan penetapan hasil akhir pemilihan yang dilakukan oleh pemerintah.

\section{DAFTAR PUSTAKA}

Andi Zainal Abidin, (1981). Hukum pidana (Peradilan Bebas \& Contempt of Court),Jakarta. Arif Miftahun Nasih Dan Anang Kistyanto, (2013) Peran Moderasi Manajemen Konfli. 1 Jurnal Ilmu Manajemen Volume 1. .

Bambang Sunggono, (2013). Metodologi Penelitian Hukum, Jakarta: Rajawali Pers.

Fisher dkk, (2002). Mengelola Konflik, Keterampilan Dan Strategi Untuk Bertindak, The British Council.

Harjana, A. M. (1994) Konflik di Tempat Kerja. Yokyakarta: Kanisius.

HR, F. S., \& Harakan, A. (2017). Eksklusivitas Adat Dalam Bingkai Demokrasi Di Indonesia. Jurnal Agregasi, 5(1).

Kanter dan S.R Sianturi, (2002). Asas-Asas Hukum Pidana di Indonesia dan Penerapannya. Jakarta: Storia Grafika.

Mukhtie Fadjar, (2013). Pemilu Perselisihan Hasil Pemilu dan Demokrasi, Malang: Setara Press. Nurul Qamar, (2013). Hak Asasi Manusia Dalam Negara Hukum Demokrasi, Jakarta: Sinar Grafika.

Safari Imama Asy’ari, (1993). Sosiologi Kota Dan Desa, Surabaya: Usaha Nasional.

Seftyono, C., Arumsari, N., Arditama, E., \& Lutfi, M. (2016). Kepemimpinan Desa dan

Pengelolaan Sumber Daya Alam Aras Lokal di Tiga Desa Lereng Gunung Ungaran, Jawa Tengah.

Otoritas: Jurnal Ilmu Pemerintahan, 6(2), 60-70.

Soekanto, Soejono, (1985). Perspektif Teoritis Studi Hukum Dalam Masyarakat, jakarta: PT Gramedia Pustaka Utama.

Wahyudi, (2011). Manajemen Konflik Dalam Organisasi, Bandung: Alfabeta.

Winardi, (2007). Manajemen Konflik (Konflik Perubahan dan Pengembangan), Bandung: Mandar Maju.

Yesmil Anwar dan Adang, (2013). Kriminologi, Bandung PT Refika Aditama. 